\title{
PENILAIAN RISIKO PADA PROSES PEMBUATAN SHEAR WALL PADA PEMBANGUNAN APARTEMEN
}

\author{
RISK ASSESSMENT IN PROCESS OF SHEAR WALL MAKING ON \\ APARTMENT DEVELOPMENT
}

\author{
Ade Jiwantyo Harjono \\ PT. Bumi Sehat Lestari \\ E-mail: adejiwantyo@rocketmail.com
}

\begin{abstract}
Based on data from the Ministry of Manpower and Transmigration at 2009, construction sector was the highest place occupational injuries. Worker in the process of manufacture shear wall at surabaya apartment should work at altitude. Working at altitude is a work that possess fatal impact in the event of an accident. Thus risk assessment is needed as one way to reduce the number of workplace accidents. The research was a descriptive-observational research using crosssectional study design. In this research, risk assessment was used qualitative methods. In the process of risk assessment, hazard identification performed by using the Job Safety Analysis (JSA) and then risk assessment was conducted use a risk matrix, so that the level of risk on the job of making shear wall could be known. The residual risk assessment was performed using guidelines calculation control. The process of making shear wall is divided into four working steps, like installation of concrete bones, installation of formwork, casting, and dismantling formwork. Result of risk assessment is pure risks of falling from height and strucked by fallen material were 15, hand being wedged were 9, irritation and being hit were 4. There is still a residual risk on falling from height and strucked by fallen material were 3, hazards of hands being wedged were 2, irritation and being hit had residual risk as many as 1. Hazards identified were dropped from height, strucked by fallen materials, wedged, irritated, and being hit. Risk assessment in existence for dropped from height and strucked by fallen material had a high risk, moderate risk for hands being wedged, being hit and irritation had a low risk. The residual risks that existed in all of these risks were low.
\end{abstract}

Keywords: hazard identification, risk assessment, residual risk

\begin{abstract}
ABSTRAK
Berdasarkan data dari Departemen Tenaga Kerja dan Transmigrasi tahun 2009, sektor konstruksi menempati urutan tertinggi dalam kecelakaan kerja. Pada proses pembuatan shear wall di apartemen surabaya tenaga kerja harus bekerja di ketinggian. Bekerja di ketinggian merupakan pekerjaan yang mempunyai dampak fatal bila terjadi kecelakaan. Sehingga perlu dilakukan analisa risiko bahaya sebagai salah satu cara untuk menurunkan angka kecelakaan kerja. Penelitian ini adalah deskriptif observasional dengan rancangan penelitian cross sectional. Pada penelitian ini penilaian risiko menggunakan metode kualitatif. Pada penilaian risiko dilakukan identifikasi bahaya menggunakan Job Safety Analysis (JSA) kemudian melakukan penilaian risiko menggunakan risk matrik, sehingga diketahui tingkat risiko pada pekerjaan pembuatan shear wall. Melakukan perhitungan risiko sisa menggunakan pedoman penilaian pengendalian. Pada proses pembuatan shear wall dibagi menjadi 4 langkah kerja seperti pemasangan tulang beton, pemasangan bekisting, pengecoran, dan pembongkaran bekisting. Hasil dari penilaian risiko adalah terjatuh dari ketinggian dan kejatuhan material risiko murni 15 , terjepit 9 , iritasi dan terpukul 4. Risiko sisa yang masih ada pada terjatuh dari ketinggian dan kejatuhan material adalah 3 , risiko bahaya tangan terjepit 2 , iritasi dan terpukul memiliki risiko sisa 1 . Bahaya yang teridentifikasi adalah terjatuh dari ketinggian, kejatuhan material, terjepit, iritasi, dan terpukul. Penilaian risiko yang ada pada terjatuh dari ketinggian dan kejatuhan material memiliki risiko tinggi, tangan terjepit risiko sedang, iritasi dan terpukul risiko rendah. Risiko sisa yang ada pada semua risiko tersebut adalah rendah.
\end{abstract}

Kata kunci: identifikasi bahaya, penilaian risiko, risiko sisa

\section{PENDAHULUAN}

Menurut Jamsostek pada tahun 2007 tercatat 65.474 kecelakaan yang mengakibatkan 1.451 orang meninggal, 5.326 orang cacat tetap dan 58.697 orang cedera. Data kecelakaan tersebut mencakup seluruh perusahaan yang menjadi anggota Jaminan Sosial Tenaga Kerja (Jamsostek) dengan jumlah 7 juta orang atau sekitar $10 \%$ dari seluruh pekerja 
di Indonesia. Angka kecelakaan mencapai 930 kejadian untuk setiap 100.000 pekerja setiap tahun. Bahkan menurut penelitian World Economic Forum tahun 2006, angka kematian akibat kecelakaan di Indonesia mencapai $17-18$ untuk setiap 100.000 pekerja (Ramli, 2013).

Menurut Septianingrum, (2012) berdasarkan data dari Departemen Tenaga Kerja dan Transmigrasi (Depnakertrans) RI (2009), bahwa sektor konstruksi menempati urutan tertinggi dalam kecelakaan kerja, yakni sebesar 32\%. Data yang diperoleh dari Menteri Tenaga Kerja dan Transmigrasi Republik Indonesia kecelakaan kerja yang terjadi di Indonesia tahun 2009 , terdapat 88.492 kasus yang mengakibatkan 1.970 tenaga kerja meninggal dunia, cacat fungsi 4.023 orang, cacat anatomis tetap 2.534 orang dan sebanyak 79.985 tenaga kerja sembuh.

Salah satu pekerjaan yang dilakukan oleh pekerja konstruksi adalah pembuatan shear wall. Shear wall, adalah dinding geser yang berfungsi untuk menahan geser akibat gaya lateral dari terjadinya gempa bumi. Menggunakan shear wall diharapkan gedung bertingkat menjadi lebih kokoh dan stabil ketika terjadi gempa. Proses pembuatan shear wall adalah dengan membuat rangkaian besi per segmen sebagai tulang beton, kemudian pemasangan bekisting sebagai cetakan beton, setelah itu dilakukan pengecoran per segmen pada tempat yang diinginkan, kemudian pembongkaran bekisting setelah beton kering.

Proyek apartemen yang berlokasi di Surabaya. Direncanakan memiliki 2 tower dengan tower A memiliki 40 lantai dan tower B memiliki 45 lantai. Mempunyai 9 lantai parkir dan 2 lantai basement.

Dalam proses pembangunan tentu saja terdapat berbagai risiko bahaya yang mungkin terjadi kepada pekerja, antara lain terjatuh dari ketinggian, tertusuk besi, tergores besi, terpeleset, tersandung, tertimpa, terpukul, dan lain-lain.

Salah satu dari kegiatan konstruksi adalah pembuatan shear wall, dalam pembuatan shear wall pekerja harus bekerja di ketinggian pada proses pembuatannya. Jika pekerja melakukan pekerjaan di tempat tinggi banyak bahaya yang dapat mengancam keselamatan pekerja jika tidak waspada.

Beberapa jenis kecelakaan yang memiliki dampak fatal menurut Health Safety and Environmental UK (2013) salah satunya adalah jatuh dari ketinggian. Setengah dari jumlah kecelakaan jatuh dari ketinggian terjadi pada sektor konstruksi mengingat banyaknya pekerjaan di sektor konstruksi yang berhubungan dengan ketinggian ditambah lagi kesadaran dari para pekerja untuk bekerja dengan aman masih sangat kurang.

Menurut Septianingrum (2012), berdasarkan data yang ada pada sektor konstruksi masih terdapat kecelakaan yang berhubungan dengan bekerja di ketinggian yaitu 13 kasus sepanjang tahun 2011. Sehingga dalam pekerjaan pembuatan shear wall yang berhubungan dengan bekerja di ketinggian mempunyai potensi untuk terjadi kecelakaan serupa bila tidak didukung manajemen K3 yang baik.

Berdasarkan Peraturan Menteri Tenaga Kerja No. 05/MEN/1996 tentang Sistem Manajemen Keselamatan dan Kesehatan Kerja (SMK3) dan Peraturan Pemerintah Republik Indonesia No. 50 tahun 2012 tentang penerapan SMK3, bahwa organisasi perusahaan yang menerapkan SMK3 wajib melakukan manajemen risiko meliputi perencanaan identifikasi bahaya, penilaian risiko, dan upaya pengendalian.

Oleh karena itu, untuk menghindari terjadinya hal tersebut maka perlu dilakukan penilaian risiko. Adanya penilaian risiko diharapkan dapat mengetahui tingkatan risiko pada suatu potensi bahaya, sehingga dapat dilakukan pengendalian untuk melindungi tenaga kerja dari kecelakaan.

Tujuan pada penelitian ini adalah melakukan analisa risiko pada proses pembuatan shear wall yang meliputi identifikasi bahaya, penilaian risiko, menentukan tingkat risiko, dan menilai risiko sisa yang masih ada setelah dilakukan pengendalian.

\section{METODE}

Ditinjau dari cara pengambilan data penelitian, maka penelitian ini adalah penelitian observasional, peneliti hanya melakukan pengamatan tanpa memberikan perlakuan dan intervensi. Berdasarkan analisisnya maka penelitian ini adalah penelitian deskriptif yaitu penelitian yang dilakukan dengan membuat gambaran tentang suatu keadaan secara objektif. Berdasarkan waktu penelitian maka penelitian ini bersifat cross sectional. Karena pengumpulan data dilakukan sekaligus pada suatu waktu tertentu. Berdasarkan dari segi tempat, penelitian ini merupakan penelitian lapangan karena mendapatkan data primer dengan melakukan wawancara dengan supervisor maupun observasi di tempat penelitian.

Teknik kualitatif merupakan teknik penilaian risiko yang menggunakan matriks risiko yang menggambarkan tingkat dari kemungkinan dan keparahan suatu kejadian yang dinyatakan dalam 
bentuk rentang dari risiko paling rendah sampai risiko paling tinggi (Suardi, 2007).

Subjek dan objek penelitian dari penelitian ini adalah sebagai berikut, subjek 1 orang supervisor $\mathrm{K} 3$, mandor, dan pekerja yang melakukan proses pembuatan shear wall pada pembangunan apartemen di Surabaya. Sedangkan objek dari penelitian adalah proses pembuatan shear wall pada pembangunan apartemen di Surabaya.

Lokasi penelitian ini pada salah satu pembangunan apartemen di Surabaya. Sedangkan untuk waktu penelitian pada bulan November 2013-Juni 2014. Variabel yang diteliti adalah identifikasi bahaya dengan menggunakan Jobs Safety Analysis (JSA), pada metode ini membagi pekerjaan menjadi langkah-langkah kerja sehingga dapat diketahui potensi bahaya di setiap tahapan suatu proses pekerjaan.

Penilaian risiko dengan mempertimbangkan kemungkinan terjadinya suatu kejadian dan besar akibat yang bisa ditimbulkan oleh suatu kejadian. Kriteria yang digunakan menggunakan standar AS/NZ 4360 : 1999 risk management guideline. Berdasarkan hasil penilaian risiko maka dapat ditentukan peringkat risiko sehingga dapat dilakukan pemilahan risiko dari yang besar sampai dengan risiko yang ringan sehingga dapat diabaikan

Menilai upaya pengendalian yang telah dilakukan untuk mengurangi risiko dengan cara menilai pengendalian berdasarkan pedoman penilaian pengendalian yang ada. Kemudian melakukan perhitungan risiko sisa yang masih ada setelah upaya pengendalian diterapkan dengan menggunakan rumus $(100 \%-\%$ nilai kontrol $) \times$ Risiko Murni (PT. Freeport Indonesia, 2008).

Teknik pengumpulan data dilakukan dengan cara datang ke tempat kerja dan melakukan penelitian secara langsung pada lokasi tujuan. Jenis data yang dikumpulkan dalam penelitian ini adalah data primer dan data sekunder. Data primer didapat melalui hasil wawancara dan observasi. Wawancara dilakukan kepada supervisor K3, mandor, dan pekerja mengenai potensi bahaya dan menilai risiko pada proses pembuatan shear wall yang dapat terjadi pada pekerja. Pengamatan secara langsung untuk melihat potensi bahaya dan menilai risiko bahaya pada proses pembuatan shear wall. Data sekunder diperoleh dari perusahaan berupa profil perusahaan, profil proyek dan data pendukung lainnya yang berhubungan dengan proses pembuatan shear wall.

Data yang sudah diperoleh saat wawancara maupun observasi diolah dengan cara menentukan likelihood dan severity sehingga bisa didapatkan nilai risiko yang kemudian dikategorikan pada tingkat risiko rendah, sedang, dan tinggi. Kemudian menentukan penilaian terhadap pengendalian yang telah diterapkan untuk menghitung risiko sisa yang masih ada. Hasil dari analisis data secara deskriptif digunakan untuk menarik kesimpulan.

\section{HASIL}

Pada proses pembuatan shear wall dibagi menjadi 4 langkah kerja seperti pemasangan tulang beton, pemasangan bekisting, pengecoran, dan pembongkaran bekisting.

Pada proses ini diawali dengan fabrikasi besi yang dikerjakan di los pekerjaan pembesian. Setelah dilakukan fabrikasi dan tulang beton terbentuk sesuai dengan yang diinginkan, lalu tulang beton tersebut diangkat menggunakan tower crane ke bagian pemasangan tulang beton. Setelah sampai pada tempat pemasangan tulang beton pekerja harus menyambung kedua tulang beton tersebut dengan cara menaiki tulang beton untuk memasang kawat benbrap dengan menggunakan gegep. Kawat dipasang pada sambungan antara tulang beton.

Pemasangan bekisting ini dilakukan sebelum dilakukan proses pengecoran. Bekisting diangkat dari bawah menggunakan sling menuju tulang beton shear wall yang akan dicor. Bagian-bagian bekisting ditempatkan sesuai dengan bentuk yang diinginkan kemudian tie rod yang ada dikencangkan menggunakan palu.

Setelah melakukan pemasangan bekisting sebagai cetakan tulang beton, kemudian cetakan tersebut dicor dengan menggunakan concrete bucket yang diangkat menggunakan tower crane. Beton ready mix dari concrete mixer truck dituangkan ke dalam concrete bucket, kemudian concrete bucket diangkat menggunakan tower crane menuju ke lokasi pengecoran. Pada saat pemindahan concrete bucket ditutup/dikunci agar tidak tumpah.

Usahakan pipa tremie sedekat mungkin dengan permukaan beton lama. Hal ini dilakukan untuk menghindari terjadinya agregat kasar terlepas dari adukan. Pengecoran dilakukan bertahap sesuai dengan bekisting yang telah dipasang. Setelah itu padatkan beton dengan concrete vibrator usahakan agar concrete vibrator tidak bersentuhan langsung dengan bekisting dan tulangan.

Pembongkaran bekisting ini dilakukan apabila adonan beton pada shear wall telah kering dan 
kokoh. Bekisting yang menjadi cetakan dibuka satu per satu dengan menggunakan palu untuk melonggarkan terot yang digunakan sebagai pengunci kemudian tiap sisi bekisting diangkat menggunakan sling menuju tempat pengecoran selanjutnya.

Pada pemasangan tulang beton bahaya yang teridentifikasi adalah terjatuh dari ketinggian, tangan terjepit, dan kejatuhan material. Pada pemasangan bekisting jatuh dari ketinggian, kejatuhan material, dan terpukul. Kemudian pada pengecoran jatuh dari ketinggian, kejatuhan material, dan iritasi. Sedangkan pada pembongkaran bekisting jatuh dari ketinggian, kejatuhan material, dan terpukul.

Pada penilaian risiko pemasangan tulang beton jatuh dari ketinggian memiliki nilai risiko 15 yang berarti risiko tinggi, tangan terjepit memiliki nilai risiko 9 yang berarti risiko sedang, dan kejatuhan material memiliki nilai risiko 15 yang berarti risiko tinggi. Pada pemasangan bekisting jatuh ketinggian memiliki nilai risiko 15 , kejatuhan material memiliki nilai risiko 15 , terpukul memiliki nilai risiko 4 . Pada proses pengecoran jatuh dari ketinggian memiliki nilai risiko 15 yang berarti risiko tinggi, kejatuhan material memiliki nilai risiko 15 yang berarti risiko tinggi, dan iritasi memiliki nilai risiko 4 yang berarti risiko rendah. Pada proses pembongkaran bekisting jatuh dari ketinggian memiliki nilai risiko 15 yang berarti risiko tinggi, kejatuhan material memiliki nilai risiko 15 yang berarti risiko tinggi, sedangkan terpukul memiliki nilai risiko 4 yang berarti risiko rendah.

Setelah diketahui nilai risiko dari tiap bahaya kemudian dilakukan pengendalian agar tidak menimbulkan kerugian bagi pekerja maupun perusahaan. Kemudian dilakukan penilaian terhadap pengendalian yang telah dilakukan dengan menggunakan pedoman penilaian pengendalian.

Hasil dari penilaian pengendalian digunakan untuk menghitung risiko sisa yang masih ada setelah dilakukan pengendalian karena penanganan bahaya tidak menjamin bahaya hilang seratus persen, sehingga masih ada risiko sisa yang harus ditanggung perusahaan (Ramli, 2011).

Pada penilaian risiko sisa pemasangan tulang beton jatuh dari ketinggian memiliki nilai risiko sisa 4 yang berarti risiko rendah, tangan terjepit memiliki nilai risiko sisa 2 yang berarti risiko rendah, dan kejatuhan material memiliki nilai risiko 4 yang berarti risiko rendah. Pada pemasangan bekisting jatuh dari ketinggian memiliki nilai risiko sisa 4 yang berarti risiko rendah, kejatuhan material memiliki nilai risiko sisa 4 yang berarti risiko rendah, dan terpukul memiliki nilai risiko 1 yang berarti risiko rendah. Pada pengecoran jatuh dari ketinggian memiliki nilai risiko sisa 4 yang berarti risiko rendah, kejatuhan material memiliki nilai risiko sisa 4 yang berarti risiko rendah, dan iritasi memiliki nilai risiko 1 yang berarti risiko rendah. Pada pembongkaran bekisting jatuh dari ketinggian memiliki nilai risiko sisa 4 yang berarti risiko rendah, kejatuhan material memiliki nilai risiko sisa 4 yang berarti risiko rendah, dan terpukul memiliki nilai risiko 1 yang berarti risiko rendah.

\section{PEMBAHASAN}

\section{Identifikasi Bahaya}

Identifikasi bahaya adalah upaya sistematis untuk mengetahui potensi bahaya yang ada di lingkungan kerja sehingga tidak menimbulkan kerugian bagi pekerja maupun perusahaan. Dalam PP No. 50 tahun 2012 tentang penerapan SMK3 disebutkan bahwa perusahaan diimbau untuk membuat rencana K3 yang salah satu isinya adalah melakukan identifikasi bahaya, penilaian risiko,

Tabel 1. Identifikasi Bahaya

\begin{tabular}{|c|c|c|}
\hline \multirow[b]{2}{*}{ Langkah Kerja } & \multicolumn{2}{|c|}{ Identifikasi Bahaya } \\
\hline & $\begin{array}{l}\text { Potensi } \\
\text { Bahaya }\end{array}$ & Penyebab \\
\hline $\begin{array}{l}\text { Pemasangan } \\
\text { Tulang Beton }\end{array}$ & $\begin{array}{l}\text { Jatuh dari } \\
\text { ketinggian } \\
\text { Tangan terjepit } \\
\text { Kejatuhan } \\
\text { material }\end{array}$ & $\begin{array}{l}\text { Platform tidak } \\
\text { kokoh, terpeleset. } \\
\text { Lengah dan tidak } \\
\text { konsentrasi saat } \\
\text { bekerja. } \\
\text { Sling putus }\end{array}$ \\
\hline $\begin{array}{l}\text { Pemasangan } \\
\text { Bekisting }\end{array}$ & $\begin{array}{l}\text { Jatuh dari } \\
\text { ketinggian } \\
\text { Kejatuhan } \\
\text { material } \\
\text { Terpukul }\end{array}$ & $\begin{array}{l}\text { Platform tidak } \\
\text { kokoh, terpeleset } \\
\text { Sling putus } \\
\text { Kurang } \\
\text { konsentrasi }\end{array}$ \\
\hline Pengecoran & $\begin{array}{l}\text { Jatuh dari } \\
\text { ketinggian } \\
\text { Kejatuhan } \\
\text { material } \\
\text { Iritasi }\end{array}$ & $\begin{array}{l}\text { Sling putus, } \\
\text { platform tidak } \\
\text { kokoh } \\
\text { Sling putus } \\
\text { Terkena cipratan } \\
\text { mortar }\end{array}$ \\
\hline $\begin{array}{l}\text { Pembongkaran } \\
\text { Bekisting }\end{array}$ & $\begin{array}{l}\text { Jatuh dari } \\
\text { ketinggian } \\
\text { Kejatuhan } \\
\text { material } \\
\text { Terpukul }\end{array}$ & $\begin{array}{l}\text { Platform tidak } \\
\text { kokoh } \\
\text { Sling putus } \\
\text { Kurang } \\
\text { konsentrasi }\end{array}$ \\
\hline
\end{tabular}


dan upaya pengendalian agar bahaya yang ada tidak menimbulkan kerugian bagi pekerja maupun perusahaan itu sendiri.

Proses untuk mengidentifikasi bahaya pada suatu pekerjaan dilakukan dengan membagi pekerjaan tersebut menjadi langkah-langkah kerja dari awal pekerjaan hingga pekerjaan tersebut selesai. Membagi pekerjaan menjadi langkahlangkah kerja maka dapat diidentifikasi bahaya yang dapat terjadi sehingga bahaya tersebut dapat lebih dini untuk dikendalikan agar tidak merugikan pekerja maupun aset perusahaan.

Pada proses pemasangan tulang beton bahaya yang teridentifikasi adalah terjatuh dari ketinggian ketika pekerja menyambung tulang beton dengan tulang beton pada segmen sebelumnya. Hal tersebut dapat terjadi apabila platform yang digunakan tidak kokoh. Selain itu penyebab bahaya terjatuh dari ketinggian adalah terpeleset saat pekerja berusaha melepaskan sling yang digunakan saat mengangkat tulang beton. Bahaya yang lain adalah tangan terjepit pada saat menyambung tulang beton hal ini disebabkan karena kurangnya koordinasi dengan sesama pekerja maupun dengan operator tower crane sehingga dapat menimbulkan cedera. Selain itu potensi bahaya yang teridentifikasi adalah kejatuhan material tulang beton, hal ini dapat terjadi bila sling putus ketika mengangkat tulang beton dan menimpa pekerja yang sedang melakukan pemasangan.

Pada pemasangan bekisting bahaya yang teridentifikasi adalah terjatuh dari ketinggian, hal ini bisa terjadi bila platform yang digunakan pekerja tidak kokoh sehingga bisa menyebabkan pekerja terjatuh dari ketinggian selain itu terpeleset saat akan melepas sling tower crane. Sling yang digunakan untuk mengangkat bekisting putus dan menimpa pekerja. Selain itu bahaya lain yang bisa terjadi pada pekerja adalah terpukul oleh palu saat mengencangkan tie rod pada bekisting.

Pada proses pengecoran bahaya yang terdidentifikasi adalah terjatuh dari ketinggian, hal ini bisa terjadi bila platform yang digunakan tidak kokoh, selain itu apabila sling yang digunakan untuk mengangkut concrete bucket putus maka bisa menyebabkan pekerja terjatuh dan concrete bucket menimpa pekerja yang sedang mengecor shear wall. Bahaya terkena tumpahan semen yang dapat menyebabkan iritasi pada mata.

Pada proses pembongkaran bekisting bahaya yang teridentifikasi adalah terjatuh dari ketinggian, hal ini bisa terjadi bila platform yang digunakan pekerja tidak kokoh sehingga bisa menyebabkan pekerja terjatuh dari ketinggian selain itu terpeleset saat menaiki bekisting untuk memasang sling tower crane. Sling yang digunakan untuk mengangkat bekisting putus sehingga menimpa pekerja yang membongkar bekisting. Selain itu bahaya lain yang bisa terjadi pada pekerja adalah terpukul oleh palu saat melonggarkan tie rod pada bekisting.

\section{Penilaian Risiko}

Penilaian risiko adalah penilaian risiko adalah proses untuk menentukan besarnya suatu risiko yang merupakan kombinasi antara kemungkinan terjadinya (kemungkinan atau likelihood) dan keparahan bila risiko tersebut terjadi (keparahan atau severity) (Ramli, 2011).

$$
\text { Risk }=\text { Likelihood } x \text { Severity }
$$

Sumber: AS/NZ 4360 : 1999 management guideline

Pada pemasangan tulang beton bahaya terjatuh dari ketinggian memiliki nilai likelihood 3 yaitu kejadian tersebut mungkin saja dapat terjadi karena pekerja menggunakan platform dari sepotong besi yang diselipkan pada tulangan beton sebelumnya sebagai pijakan. Severity memiliki nilai 5 yaitu menyebabkan kematian bagi pekerja bila bahaya tersebut terjadi. Berdasarkan hasil perkalian antara likelihood dan severity memiliki nilai 15 , maka jatuh dari ketinggian memiliki kategori risiko bahaya tinggi.

Berdasarkan kriteria penilaian maka pekerjaan tidak dapat diteruskan. Dilakukan pengendalian untuk mereduksi risiko yang ada sehingga tidak membahayakan bagi pekerja.

Pada potensi bahaya terjepit memiliki nilai likelihood 3 yaitu kejadian tersebut mungkin saja dapat terjadi karena pada saat melakukan pemasangan pekerja tidak menggunakan cotton gloves. Severity memiliki nilai 3 yaitu diperlukan pertolongan medis dan luka dapat menimbulkan kehilangan waktu kerja. Berdasarkan hasil perkalian antara likelihood dan severity memiliki nilai 9, maka terjepit memiliki kategori risiko sedang.

Berdasarkan kriteria penilaian maka pekerjaan dapat diteruskan dengan keputusan manajemen yang baik setelah konsultasi dengan tenaga ahli dan tim penilaian. Bila memungkinkan pekerjaan akan ditetapkan ulang untuk memperhitungkan bahaya yang terlibat atau selanjutnya risiko direduksi dahulu sebelum memulai pekerjaan.

Potensi bahaya kejatuhan material memiliki nilai likelihood 3 yaitu kejadian tersebut mungkin 
saja dapat terjadi karena sling yang digunakan tidak dilakukan pengecekan sebelum memulai pekerjaan sedangkan sling tower crane digunakan untuk mengangkat benda berat selama seharian. Kemudian untuk severity memiliki nilai 5 yaitu menyebabkan kematian bagi pekerja bila bahaya tersebut terjadi karena tertimpa material tulangan beton. Berdasarkan hasil perkalian antara likelihood dan severity memiliki nilai 15 , maka kejatuhan material memiliki kategori risiko tinggi. Berdasarkan kriteria penilaian maka pekerjaan tidak dapat diteruskan. Dilakukan pengendalian untuk mereduksi risiko yang ada sehingga tidak membahayakan bagi pekerja.

Pada pemasangan bekisting bahaya terjatuh dari ketinggian memiliki nilai likelihood 3 yaitu kejadian tersebut mungkin saja dapat terjadi. Kemudian untuk severity memiliki nilai 5 yaitu menyebabkan kematian bagi pekerja bila bahaya tersebut terjadi. Berdasarkan hasil perkalian antara likelihood dan severity memiliki nilai 15 , maka jatuh dari ketinggian memiliki kategori risiko bahaya tinggi. Berdasarkan kriteria penilaian maka pekerjaan tidak dapat diteruskan. Dilakukan pengendalian untuk mereduksi risiko yang ada sehingga tidak membahayakan bagi pekerja.

Potensi bahaya kejatuhan material memiliki nilai likelihood 3 yaitu kejadian tersebut mungkin saja dapat terjadi karena sling yang digunakan tidak dilakukan pengecekan rutin sebelum memulai pekerjaan sedangkan sling tower crane digunakan untuk mengangkat benda berat selama seharian. Kemudian untuk severity memiliki nilai 5 yaitu menyebabkan kematian bagi pekerja bila bahaya tersebut terjadi. Berdasarkan hasil perkalian antara likelihood dan severity memiliki nilai 15 , maka kejatuhan material memiliki kategori risiko tinggi.

Berdasarkan kriteria penilaian maka pekerjaan tidak dapat diteruskan. Dilakukan pengendalian untuk mereduksi risiko yang ada sehingga tidak membahayakan bagi pekerja.

Bahaya terpukul memiliki nilai likelihood 2 yaitu peristiwa dapat terjadi hanya pada keadaan tertentu. Untuk severity memiliki nilai 2 yaitu luka ringan hanya diperlukan pertolongan pertama. Berdasarkan hasil perkalian antara likelihood dan severity memiliki nilai 4 , maka terpukul memiliki kategori risiko rendah. Berdasarkan kriteria penilaian maka pekerjaan dapat diteruskan bila memungkinkan risiko dapat dikurangi.

Pada pengecoran bahaya terjatuh dari ketinggian memiliki nilai likelihood 3 yaitu kejadian tersebut mungkin saja dapat terjadi. Kemudian untuk severity memiliki nilai 5 yaitu menyebabkan kematian bagi pekerja bila bahaya tersebut terjadi. Berdasarkan hasil perkalian antara likelihood dan severity memiliki nilai 15 , maka jatuh dari ketinggian memiliki kategori risiko bahaya tinggi.

Berdasarkan kriteria penilaian maka pekerjaan tidak dapat diteruskan. Dilakukan pengendalian untuk mereduksi risiko yang ada sehingga tidak membahayakan bagi pekerja.

Potensi bahaya kejatuhan material memiliki nilai likelihood 3 yaitu kejadian tersebut mungkin saja dapat terjadi karena sling yang digunakan tidak dilakukan pengecekan sebelum memulai pekerjaan sedangkan sling tower crane digunakan untuk mengangkat benda berat selama seharian. Kemudian untuk severity memiliki nilai 5 yaitu menyebabkan kematian bagi pekerja bila bahaya tersebut terjadi. Berdasarkan hasil perkalian antara likelihood dan severity memiliki nilai 15 , maka kejatuhan material memiliki kategori risiko tinggi.

Berdasarkan kriteria penilaian maka pekerjaan tidak dapat diteruskan. Dilakukan pengendalian untuk mereduksi risiko yang ada sehingga tidak membahayakan bagi pekerja.

Sedangkan bahaya iritasi memiliki nilai likelihood 2 yaitu peristiwa dapat terjadi hanya pada keadaan tertentu. Kemudian untuk severity memiliki nilai 2 yaitu luka ringan hanya diperlukan pertolongan pertama. Berdasarkan hasil perkalian antara likelihood dan severity memiliki nilai 4, maka iritasi memiliki kategori risiko rendah. Berdasarkan kriteria penilaian maka pekerjaan dapat diteruskan bila memungkinkan risiko dapat dikurangi.

Pada pembongkaran bekisting bahaya terjatuh dari ketinggian memiliki nilai likelihood 3 yaitu kejadian tersebut mungkin saja dapat terjadi. Kemudian untuk severity memiliki nilai 5 yaitu menyebabkan kematian bagi pekerja bila bahaya tersebut terjadi. Berdasarkan hasil perkalian antara likelihood dan severity memiliki nilai 15 , maka jatuh dari ketinggian memiliki kategori risiko bahaya tinggi.

Berdasarkan kriteria penilaian maka pekerjaan tidak dapat diteruskan. Dilakukan pengendalian untuk mereduksi risiko yang ada sehingga tidak membahayakan bagi pekerja.

Potensi bahaya kejatuhan material memiliki nilai likelihood 3 yaitu kejadian tersebut mungkin saja dapat terjadi karena sling yang digunakan tidak dilakukan pengecekan rutin sebelum memulai pekerjaan sedangkan sling tower crane digunakan 
untuk mengangkat benda berat selama seharian. Kemudian untuk severity memiliki nilai 5 yaitu menyebabkan kematian bagi pekerja bila bahaya tersebut terjadi. Berdasarkan hasil perkalian antara likelihood dan severity memiliki nilai 15 , maka kejatuhan material memiliki kategori risiko tinggi.

Berdasarkan kriteria penilaian maka pekerjaan tidak dapat diteruskan. Dilakukan pengendalian untuk mereduksi risiko yang ada sehingga tidak membahayakan bagi pekerja.

Bahaya terpukul memiliki nilai likelihood 2 yaitu peristiwa dapat terjadi hanya pada keadaan tertentu. Untuk severity memiliki nilai 2 yaitu luka ringan hanya diperlukan pertolongan pertama. Berdasarkan hasil perkalian antara likelihood dan severity memiliki nilai 4 , maka terpukul memiliki kategori risiko rendah. Berdasarkan kriteria penilaian maka pekerjaan dapat diteruskan bila memungkinkan risiko dapat dikurangi.

\section{Penilaian Pengendalian}

Pada pemasangan tulang beton pengendalian yang dilakukan pada bahaya terjatuh dari ketinggian adalah terdapat SOP untuk bekerja di ketinggian yang harus dijalankan oleh pekerja yang akan bekerja di ketinggian, kemudian membuat platform yang kokoh bagi pekerja yang akan bekerja memasang tulang beton dan menggunakan sepatu karet untuk menghindari terpeleset saat menaiki tulangan beton, selain itu pengendalian yang sudah dilakukan adalah melakukan pengawasan terhadap pekerja dengan cara safety patrol oleh petugas safety supervisor.

Penilaian pengendalian terhadap bahaya jatuh dari ketinggian memiliki nilai efektivitas $75 \%$ yaitu pengendalian yang ada diimplementasikan dengan baik dan berfungsi. Tetapi masih ada celah yang harus diperbaiki seperti masih ada pekerja tidak menggunakan body harness, dan lanyard tidak dikaitkan, selain itu masih ada pekerja menggunakan platform yang tidak kokoh pada saat bekerja.

Bahaya yang lain adalah tangan terjepit, pengendalian yang dilakukan adalah dengan memberikan APD yaitu cotton gloves bagi pekerja yang melakukan pemasangan tulang beton, melakukan koordinasi dengan operator tower crane dan pekerja lain.

Penilaian pengendalian terhadap bahaya tangan terjepit memiliki nilai efektivitas $75 \%$ yaitu pengendalian yang ada diimplementasikan dengan baik dan berfungsi. Tetapi masih ada celah yang harus diperbaiki seperti masih ada pekerja yang tidak menggunakan cotton gloves pada saat bekerja memasang tulang beton.

Selain itu potensi bahaya yang teridentifikasi adalah kejatuhan material tulang beton. Pengendalian yang dilakukan adalah melakukan koordinasi dengan operator tower crane dan pekerja lain, serta adanya SOP pengoperasian tower crane, dan SOP pemeriksaan, pemakaian, dan pemeliharaan sling/ tali baja.

Penilaian pengendalian terhadap bahaya kejatuhan material tulang beton memiliki nilai efektivitas $75 \%$ yaitu pengendalian yang ada diimplementasikan dengan baik dan berfungsi. Tetapi masih ada celah yang harus diperbaiki yaitu belum adanya pengecekan sling tower crane sebelum digunakan.

Pada pemasangan bekisting bahaya terjatuh dari ketinggian tindakan pengendalian yang dilakukan adalah terdapat SOP untuk bekerja di ketinggian, kemudian membuat platform yang kokoh bagi pekerja, menggunakan sepatu karet bagi pekerja untuk menghindari terpeleset saat menaiki bekisting dan melakukan pengawasan terhadap pekerja yang bekerja di ketinggian.

Penilaian pengendalian terhadap bahaya jatuh dari ketinggian memiliki nilai efektivitas $75 \%$ yaitu pengendalian yang ada diimplementasikan dengan baik dan berfungsi. Tetapi masih ada celah yang harus diperbaiki seperti masih ada pekerja tidak menggunakan body harness dan lanyard tidak dikaitkan pada saat bekerja di ketinggian.

Selain itu potensi bahaya yang teridentifikasi adalah kejatuhan bekisting. Pengendalian yang telah dilakukan adalah terdapat SOP pengoperasian tower crane, dan SOP pemeriksaan, pemakaian, dan pemeliharaan sling/tali baja.

Penilaian pengendalian terhadap bahaya kejatuhan bekisting memiliki nilai efektivitas $75 \%$ yaitu pengendalian yang ada diimplementasikan dengan baik dan berfungsi. Tetapi masih ada celah yang harus diperbaiki yaitu belum adanya pengecekan sling tower crane sebelum digunakan.

Pada bahaya terpukul pengendalian yang telah dilakukan adalah memberikan APD berupa cotton gloves kepada pekerja. Penilaian pengendalian terhadap bahaya terpukul memiliki nilai efektivitas $75 \%$ yaitu pengendalian yang ada diimplementasikan dengan baik dan berfungsi, tetapi masih ada celah yang harus diperbaiki yaitu pekerja tidak menggunakan cotton gloves saat bekerja.

Pada pengecoran bahaya jatuh dari ketinggian pengendalian yang telah dilakukan adalah terdapat 
SOP untuk bekerja di ketinggian, SOP pemeriksaan, pemakaian, dan pemeliharaan sling/tali baja, kemudian membuat platform yang kokoh bagi pekerja yang melakukan pengecoran, dan melakukan pengawasan terhadap pekerja.

Penilaian pengendalian terhadap bahaya jatuh dari ketinggian memiliki nilai efektivitas $75 \%$ yaitu pengendalian yang ada diimplementasikan dengan baik dan berfungsi, tetapi masih ada celah yang harus diperbaiki yaitu pekerja tidak mengaitkan lanyard saat bekerja.

Pada bahaya kejatuhan material pengendalian yang telah dilakukan terdapat SOP pengoperasian tower crane, SOP pemeriksaan, pemakaian, dan pemeliharaan sling/tali baja.

Penilaian pengendalian terhadap bahaya kejatuhan material memiliki nilai efektivitas $75 \%$ yaitu pengendalian yang ada diimplementasikan dengan baik dan berfungsi, tetapi masih ada celah yang harus diperbaiki yaitu belum adanya pengecekan sling tower crane sebelum digunakan.

Sedangkan pada bahaya iritasi pengendalian yang dilakukan adalah memberikan APD yaitu safety google dan cotton gloves bagi pekerja. Penilaian pengendalian terhadap bahaya iritasi memiliki nilai efektivitas $75 \%$ yaitu pengendalian yang ada diimplementasikan dengan baik dan berfungsi, tetapi masih ada pekerja yang tidak menggunakan APD tersebut ketika melakukan pengecoran.

Pada pembongkaran bekisting bahaya terjatuh dari ketinggian tindakan pengendalian yang dilakukan adalah terdapat SOP untuk bekerja di ketinggian, kemudian membuat platform yang kokoh bagi pekerja, menggunakan sepatu karet bagi pekerja untuk menghindari terpeleset saat menaiki bekisting dan melakukan pengawasan terhadap pekerja yang bekerja di ketinggian.

Penilaian pengendalian terhadap bahaya jatuh dari ketinggian memiliki nilai efektivitas $75 \%$ yaitu pengendalian yang ada diimplementasikan dengan baik dan berfungsi. Tetapi masih ada celah yang harus diperbaiki seperti masih ada pekerja tidak menggunakan body harness dan tidak mengaitkan lanyard pada saat bekerja di ketinggian.

Selain itu potensi bahaya yang teridentifikasi adalah kejatuhan bekisting. Pengendalian yang telah dilakukan adalah terdapat SOP pengoperasian tower crane, dan SOP pemeriksaan, pemakaian, dan pemeliharaan sling/tali baja.

Penilaian pengendalian terhadap bahaya kejatuhan bekisting memiliki nilai efektivitas $75 \%$ yaitu pengendalian yang ada diimplementasikan dengan baik dan berfungsi. Tetapi masih ada celah yang harus diperbaiki yaitu tidak dilakukan pengecekan sling tower crane sebelum pekerjaan dilakukan.

Pada bahaya terpukul pengendalian yang telah dilakukan adalah memberikan APD berupa cotton gloves kepada pekerja. Penilaian pengendalian terhadap bahaya terpukul memiliki nilai efektivitas $75 \%$ yaitu pengendalian yang ada diimplementasikan dengan baik dan berfungsi, tetapi masih ada celah yang harus diperbaiki yaitu masih ada pekerja yang tidak menggunakan APD tersebut saat bekerja.

\section{Risiko Sisa}

Risiko sisa adalah risiko yang masih ada setelah dilakukan pengendalian terhadap bahaya yang teridentifikasi. Pengendalian risiko tidak menjamin risiko atau bahaya hilang seratus persen, sehingga masih ada risiko sisa (residual risk) yang harus ditanggung perusahaan (Ramli, 2011). Cara penentuan peringkat risiko sisa adalah menentukan persentase tingkat efektivitas alat kontol yang ada berdasarkan pedoman penilaian kontrol menentukan risiko sisa dengan menggunakan perhitungan $100 \%$ - efektivitas kontrol, misal efektivitas kontrol adalah $75 \%$ maka $100-75 \%$ $=25 \%$. Sehingga didapat faktor risiko sisa 0,25 mengalikan risiko murni dengan faktor risiko sisa, misal risiko murni 20 maka $20 \times 0,25=5$. Maka risiko sisa adalah 5 .

Pada pemasangan tulang beton penilaian pengendalian terhadap bahaya jatuh dari ketinggian memiliki nilai efektivitas $75 \%, 100-75 \%=25 \%$. Sehingga perhitungan risiko sisa $15 \times 0,25=4$, maka risiko sisa yang ada termasuk pada kategori risiko rendah dan risiko bahaya dapat diterima dan pekerjaan dapat diteruskan.

Penilaian pengendalian terhadap bahaya tangan terjepit memiliki nilai efektivitas $75 \%, 100-75 \%=$ $25 \%$. Sehingga perhitungan risiko sisa $9 \times 0,25=2$, maka risiko sisa yang ada termasuk pada kategori risiko rendah dan risiko bahaya dapat diterima dan pekerjaan dapat diteruskan.

Penilaian pengendalian terhadap bahaya kejatuhan material tulang beton memiliki nilai efektivitas $75 \%, 100-75 \%=25 \%$. Sehingga perhitungan risiko sisa $15 \times 0,25=4$, maka risiko sisa yang ada termasuk pada kategori risiko rendah dan risiko bahaya dapat diterima dan pekerjaan dapat diteruskan.

Pada pemasangan bekisting penilaian pengendalian terhadap bahaya jatuh dari ketinggian 
memiliki nilai efektivitas $75 \%, 100-75 \%=25 \%$. Sehingga perhitungan risiko sisa $15 \times 0,25=4$, maka risiko sisa yang ada termasuk pada kategori risiko rendah dan risiko bahaya dapat diterima dan pekerjaan dapat diteruskan.

Penilaian pengendalian terhadap bahaya kejatuhan bekisting memiliki nilai efektivitas $75 \%$, $100-75 \%=25 \%$. Sehingga perhitungan risiko sisa $15 \times 0,25=4$, maka risiko sisa yang ada termasuk pada kategori risiko rendah dan risiko bahaya dapat diterima dan pekerjaan dapat diteruskan.

Penilaian pengendalian terhadap bahaya terpukul memiliki nilai efektivitas $75 \%, 100-75 \%$ $=25 \%$. Sehingga perhitungan risiko sisa $4 \times 0,25=$ 1 , maka risiko sisa yang ada termasuk pada kategori risiko rendah dan risiko bahaya dapat diterima dan pekerjaan dapat diteruskan.

Pada pengecoran penilaian pengendalian terhadap bahaya jatuh dari ketinggian memiliki nilai efektivitas $75 \%, 100-75 \%=25 \%$. Sehingga perhitungan risiko sisa $15 \times 0,25=4$, maka risiko sisa yang ada termasuk pada kategori risiko rendah dan risiko bahaya dapat diterima dan pekerjaan dapat diteruskan.

Penilaian pengendalian terhadap bahaya kejatuhan material memiliki nilai efektivitas $75 \%$, $100-75 \%=25 \%$. Sehingga perhitungan risiko sisa $15 \times 0,25=4$, maka risiko sisa yang ada termasuk pada kategori risiko rendah dan risiko bahaya dapat diterima dan pekerjaan dapat diteruskan.

Penilaian pengendalian terhadap bahaya iritasi memiliki nilai efektivitas $75 \%, 100-75 \%=25 \%$. Sehingga perhitungan risiko sisa $4 \times 0,25=1$, maka risiko sisa yang ada termasuk pada kategori risiko rendah dan risiko bahaya dapat diterima dan pekerjaan dapat diteruskan.

Pada pembongkaran bekisting, penilaian pengendalian terhadap bahaya jatuh dari ketinggian memiliki nilai efektivitas $75 \%, 100-75 \%=25 \%$. Sehingga perhitungan risiko sisa $15 \times 0,25=4$, maka risiko sisa yang ada termasuk pada kategori risiko rendah dan risiko bahaya dapat diterima dan pekerjaan dapat diteruskan.

Penilaian pengendalian terhadap bahaya kejatuhan bekisting memiliki nilai efektivitas $75 \%$, $100-75 \%=25 \%$. Sehingga perhitungan risiko sisa $15 \times 0,25=4$, maka risiko sisa yang ada termasuk pada kategori risiko rendah dan risiko bahaya dapat diterima dan pekerjaan dapat diteruskan.
Penilaian pengendalian terhadap bahaya terpukul memiliki nilai efektivitas $75 \%, 100-75 \%$ $=25 \%$. Sehingga perhitungan risiko sisa $4 \times 0,25=$ 1 , maka risiko sisa yang ada termasuk pada kategori risiko rendah dan risiko bahaya dapat diterima dan pekerjaan dapat diteruskan.

\section{SIMPULAN}

Bahaya yang teridentifikasi pada proses pembuatan shear wall pada pembangunan SOHO dan Ciputra Surabaya antara lain terjatuh dari ketinggian, kejatuhan material, terjepit, iritasi, dan terpukul.

Berdasarkan hasil penilaian risiko bahaya pada proses pembuatan shear wall terjatuh dari ketinggian dan kejatuhan material memiliki nilai 15 , tangan terjepit memiliki nilai 9, iritasi dan terpukul memiliki nilai 4.

Berdasarkan hasil penilaian risiko bahaya pada proses pembuatan shear wall maka tingkat risiko terjatuh dari ketinggian dan kejatuhan material termasuk risiko tinggi, tangan terjepit termasuk kategori sedang, iritasi dan terpukul termasuk kategori rendah.

Risiko sisa yang masih ada setelah dilakukan pengendalian pada risiko bahaya terjatuh dari ketinggian dan kejatuhan material adalah 3 , risiko bahaya tangan terjepit 2 , iritasi dan terpukul memiliki risiko sisa 1 .

\section{DAFTAR PUSTAKA}

Madill. Ken/AS/NZS 4360:1999 Risk Management/ http://www.schleupen.de/content/schleupen/ schleupen013223/A.4.1.4_Australia_ and_New_Zealand_Methodology_AS NZ\%25204360_1999.pdf. (tanggal sitasi 17 April 2014).

Peraturan Menteri Tenaga Kerja Nomor PER. 05/MEN/1996 tentang Sistem Manajemen Keselamatan dan Kesehatan Kerja. Jakarta: Kementerian Tenaga Kerja.

Peraturan Pemerintah Republik Indonesia No. 50 Tahun 2012 tentang Penerapan Sistem Manajemen Keselamatan dan Kesehatan Kerja. Jakarta: Kementerian Tenaga Kerja.

PT. Freeport Indonesia. 2008. Risk Assessment. Tembagapura: HSE. 
Ramli, Soehatman. 2011. Pedoman Praktis Manajemen Risiko dalam Perspektif K3 OHS Risk Management. Jakarta: Dian Rakyat.

Ramli, Soehatman. 2013. Sistem Manajemen Keselamatan dan Kesehatan Kerja OHSAS 18001. Jakarta: Dian Rakyat.

Suardi, Rudi. 2007. Sistem Manajemen Keselamatan dan Kesehatan Kerja. Jakarta: PPM
Septianingrum, Winda Utami. 2012. Penilaian Risiko Keselamatan Kerja pada Proses Pemasangan Ring Kolom dan Pemasangan Bekisting di Ketinggian pada Pembangunan Gedung XY Oleh PT. X Tahun 2011. Skripsi. Jakarta: Universitas Indonesia, 2. 